\title{
AGREEEMENT BETWEEN MEASUREMENT OF JUMP HEIGHT IN DIFFERENT VERTICAL JUMP TESTS EXECUTED BY YOUNG FOOTBALL PLAYERS
}

\author{
Marin Gadev, Petar Peev, Oleg Hristov \\ National Sports Academy "Vassil Levski", Sofia, Bulgaria
}

\section{ORCID (D)}

Marin Gadev https://orcid.org/0000-0003-1490-5946

Oleg Hristov https://orcid.org/0000-0003-2240-4375

Petar Peev https://orcid.org/0000-0003-1402-5121

\begin{abstract}
Football is an intermittent sport with a great number of short and explosive actions. These characteristics of the game require a good level of anaerobic power. The main field tests used as indicators of the development of the anaerobic energy system were the jumps in the vertical plane. The same tests also measured the strength of the lower limbs. We presume that the explosive power of the lower limbs characterizes the development of the alactic anaerobic energy system and strength capacity at the same time. In that case the explosive power of the lower limbs was an important component of the conditioning and strength training of football players. There was a great variety of methods and devices which registered vertical jump height. From this point of view, we wanted to add our study to the research work in the specialized literature. The purpose of this study was to analyze the differences of the jump height measured via two devices. We used the following methods of research: accelerometry, chronometry and statistical analysis. We studied the vertical jump height of 32 football players of the Youth Academy of PFC "Levski"-Sofia at the age of 13,4. In the research the participants performed three jump tests (squat jump [SJ], counter movement jump [CMJ] and counter movement jump with arm swing [CMJA]) as the jump height was measured via accelerometer and Infrared platform. The results from these two devices were compared via Bland Altman plot and calculation of Intraclass correlation coefficients [ICC]. The results of ICC between the two devices showed very strong correlation of the results for the three tests $(S J(R=.91), C M J(R=.92)$ and $C M J A(R=.87))$. The results of the ANOVA showed statistical difference between the measured jump heights $(p<.05$ for all test, systematic bias was equal to: $S J=15.6 ; C M J=15.2 ; C M J A=19.5$ and effect size $\left(\eta^{2}\right)$ was large $S J=.65 ; C M J=.69 ; C M J A=.65)$ for the three different types of jump. Conclusions: 1 ) Both of the devices showed good consistency of the collected results; 2) The data collected from the two devices showed significant difference of the jump heights.
\end{abstract}

Key words: football, vertical jump, team sports, testing, validity.

\section{INTRODUCTION}

The explosive power of the lower limbs is an important component of conditioning and strength training. The character of the game predetermines great requirements on anaerobic explosive actions (Di Salvo et al., 2013).
It is known that explosive power is related to the maximal speed and acceleration capability (Nordin et al., 2014; Peev, 2014; McFarland et al., 2016; Rouis et al., 2016). At the same time, a great number of sport professionals specify the quantitative values of explosive 
power as a method for control, selection and prediction of capabilities of the young players (Klavora, 2000; Markovic et al., 2004; Cunha et al., 2017). Some authors even offer indirect assessment of anaerobic power based on the values of jump height (Hoffman and Kang, 2002; Balsalobre-Fernandez et al., 2014; Laffaye et al., 2014).

The vertical jumps were reliable and popular tests for determining the explosive power of the lower limbs of athletes. At the same time, they were tests which measured the muscle strength of different muscular efforts (concentric, eccentric and the stretch-shortening cycle muscle function). Other frequently used tests were the squat jump [SJ], the counter movement jump [CMJ] and the counter movement jump with arm swing [CMJA] (Kibele, 1998; Enoksen et al., 2009). The establishment of the jump height in test exercises was done by various devices and methods such as contact plates, force plates, infrared platforms, linear position transducer, accelerometer and video analysis (Hatze, 1998; Haugen et al., 2013; Klavora, 2000; Markovic et al., 2004; Nordin et al., 2014). Based on this variety of methods and devices, our desire was to help for the proper understanding of this problem. There are many surveys (Garcia-Lopez et al., 2005; Leard et al., 2007; Moir et al., 2008; Buckthorpe et al., 2012; Monnet, 2014) which compare different methods and devices but in our research we used devices which had not been studied before. Another novelty for science is the type of research with young football players which, to our knowledge, has not been done so far. It will be extremely useful for analysis and correct comparison of the results from these tests for physical education teachers and conditioning specialists. As Haugen et al. (2013) observe there was no progress in the jump height between 1995 and 2010 but at the same time the sprinting speed increased slightly. In this line of thought, there were reserves in the jumping performance of football players that physical education teachers and conditioning specialists could exploit. Both Rampinini et al. (2007) and Haugen et al. (2013) came to the same conclusion about elite and non-elite players. As we mentioned above, there is a relationship between sprinting and jumping performance and it is unlikely for individuals with poor leg explosive power to meet modern football requirements completely.

The development of technology has led to greater precision of the devices used. In general, this research wanted to verify and double check this problem and, in addition to previous research, to investigate the concurrent validity of the two devices that were previously mentioned. Another focus of our research was to find a model for transforming the device results, because we could not find papers or equations on this matter in the existing literature.

All these considerations led to the purpose of our study, which was to investigate the concurrent validity and reliability of devices for measurement of the jump height.

The objectives of the present study were:

1. To establish the average jump height among different devices that measured vertical jump performance;

2. To specify the relationship between the results of the two devices for measuring the vertical jump performance and their respective differences;

3 . To create a model for comparison of the results of the two devices that measured vertical jump performance.

\section{METHODS}

\section{Study design}

Our research wanted to give answer to the question about the concurrent validity of two 
measurement devices that register jump height. We didn't use gold "standard" devices because we did field testing and they were not appropriate for that kind of research. Both devices were simultaneously used on a specific subject so we could compare the results via both devices. In order to solve the assigned tasks, we used the following methods of research: accelerometry, chronometry which had been integrated in the two devices (G-walk sensor and Infrared platform) At the end we summarised the received and made statistical analysis with the following methods: descriptive statistic, Shapiro-Wilk normality test, Intraclass correlation, ANOVA and Bland-Altman plot.

\section{Subjects of the research}

The tested subjects of our research were $32(162.6 \pm 8 \mathrm{~cm} ; 49.5 \pm 6.3 \mathrm{~kg})$ adolescent football players from Youth Academy of PFC „Levski”- Sofia at the age of 13.4 with at least 4 years of training experience.

Voluntary informed consent was obtained from all players before the study began. Ethics approval for the tests was granted by the University Human Research Ethics Committee. Written permission from the club and the parents was received to record and analyze the data.

\section{Instruments}

The jump height was recorded using a 200 $\mathrm{Hz}$ inertial G-Walk sensor (BTS Bioengeniering, Italy) and Infrared platform (IR) - OptojumpNext (Microgate, Bolzano, Italy) with a capture frequency of $1000 \mathrm{~Hz}$. The device (G-walk) had integrated in it a tri-axial accelerometer (with sensitivity \pm 1.5 - $\pm 6 \mathrm{~g}$ ), a tri-axial magnetometer, and a tri-axial gyroscope (with sensitivity $\pm 300- \pm 1200$ gps). These microsensors allowed it to detect and record accelerations and vertical displacement of the centre of mass $[\mathrm{CM}]$. All the data were sent via Bluetooth to a personal computer with installed special software (BTS G-Studio) where all the calculations were made. The data of IR were obtained from the photoelectric cells built in 1-meter-long parallel bars (receiver and transmitter). The transmitter contains 100 diodes emitting infrared light, positioned $3 \mathrm{~mm}$ from ground level at $10 \mathrm{~mm}$ intervals. The system measures the flight time of a jump with a frequency of $1 / 1000$ seconds $(1 \mathrm{kHz})$. The Optojump bars were connected to a personal computer with the proprietary software which instantly provides the measured outcomes. The Optojump Next software calculates the height of vertical jump based of flight time using the formula $\left(\left(\mathrm{g}^{*}\right.\right.$ flight time $\left.\left.^{2}\right) / 8\right)$ described by Bosco et. al (1983) (where $\mathrm{g}$ is gravitational acceleration that is equal to $9.81 \mathrm{~m} / \mathrm{s}^{2}$ ). The Optojump bars were placed $2 \mathrm{~m}$ apart parallel to each other on a flat surface.

\section{Procedures}

Detailed descriptions of the execution of the test are explained in the following paragraphs and are graphically presented in Figure 1:

Squat Jump was preformed from a starting position with a flexion at the knee joint approximately at 90 degrees with visual confirmation. The feet were shoulder width apart with plantar part of the feet contacting the ground and the hands were on waist throughout the exercise. The trunk was erected. From this position, the legs were extended quickly with maximum power in order to reach maximum height. The lower limbs were extended until the landing (Figure $1 \mathrm{~A}$ ). We use this test to check the concentric muscle power of the lower limbs.

Counter Movement Jump was executed from a standing starting position. The feet were shoulder width apart plantar part of the feet contacting the ground and the hands were on the waist throughout the exercise. From this position a quick flexion at the knee 
joint approximately 90 degrees with visual confirmation (main goal was to do a rapid downwards movement) followed by extension of the lower limbs and jump upwards with the goal of achieving maximum height. The lower limbs were extended until the landing (Figure $1 \mathrm{~B}$ ). With this test we wanted to reveal the stretch-shortening cycle muscle function, as it is closer to a match-playing situation.

Counter Movement Jump with Arm Swing was executed from a standing starting position. The feet were shoulder width apart and the hands were lifted above the head. From this position a quick flexion on the knee joint approximately 90 degrees with visual confirmation in coordination with rapid lowering of the arms (Figure $1 \mathrm{C}-2$ ). This movement was followed by extension of the lower limbs in coordination with swinging motion of the arms up (Figure 1 C-3) and a jump upwards with the goal of achieving maximum height without lowering of the arms. The lower limbs were extended until the landing (Figure $1 \mathrm{C}-4)$. The test helps us to find the muscle power of the lower extremities in condition that are as close as possible to playing in a football match.

Testing was conducted at the end of the competitive season within one day. The tests took place in a single session with simultaneous use of both measuring devices. The athletes were introduced to the testing procedures and techniques prior to the examination as a part of their usual testing battery. The testing battery included: Vertical jump tests (made in this order SJ, CMJ and CMJA), Sprint test (20 $\mathrm{m}$ dash running), Aerobic capacity test (Vameval test) and technical tests (dribbling, joggling and passing). In this research we used only the jumps test results.

The football players did the tests after a stan- dard warm up consisting of 6 minutes riding an exercise bike, dynamic stretching, squatting and two test tries without their registration or measuring devices. The test was conducted in an indoor facility with a flat floor. The players stood in a closed space restricted by the side bars of Optojump, which created a coordinate system, and wore their waist belts with accelerometers attached in a specially designed pocket. Every player was verbally supported and instructed to jump as high as he could. The three tests were conducted one after another in this order: SJ, CMJ and CMJA. We used three tests SJ, CMJ and CMJA in that order to standardize the results and eliminated the errors and difference in performance caused by fatigue. The players did two trials with the devices in every type of jump and we used the better one. All subjects of the research rested for 30 second between the trials. The right execution of the jump was observed visually and that was a condition for continuing with the next jump.

\section{Statistical analysis}

Descriptive statistics was used to receive the average value $(\overline{\mathrm{X}})$ and standard deviation (SD) of the jump height for all of the above-mentioned tests. We used the Shapiro-Wilk normality test to define the normality of the received data. When we proved the normality, we used the ICC to define the interrelationship of the results for every participant in the tests. We compared the results of the jump height using ANOVA, with the alpha level set at $p<.05$, to identify the measurement differences of the two devices and at the end we illustrated them graphically with the Bland-Altman plot.

All statistical procedures were done using SPSS Statistics ver. 19 software (IBM Corp., Armonk, NY). The procedures were made according to Damyanova (2012). 


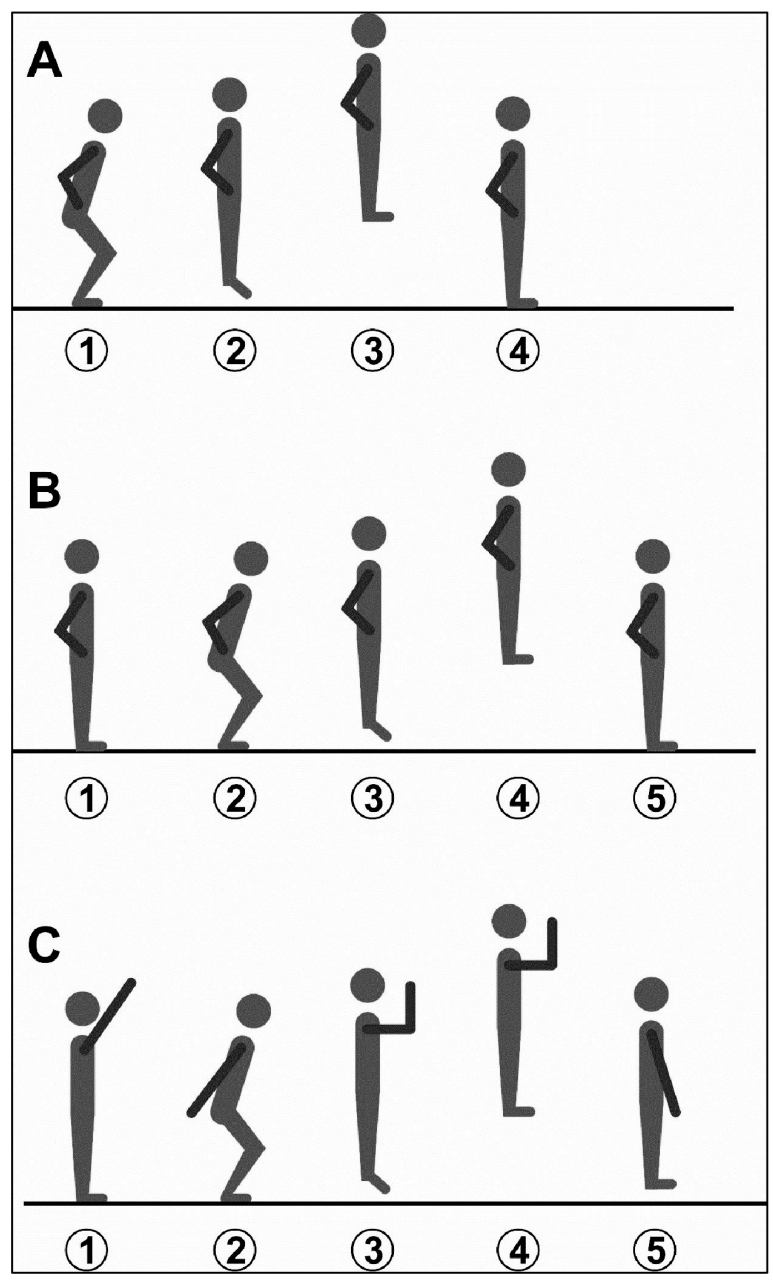

Figure 1. Graphic display of the performance of the tests (SJ $(A), C M J(B)$ and $C M J A(C))$

\section{RESULTS}

The results of the descriptive statistics of the jump height in different types of jumps can be seen in Table 1. The coefficient of variation
$[\mathrm{CV} \%]$ for the measured parameters with both measuring devices was between $12.00 \%$ and $16.20 \%$, which defines the research parameters with middle dispersion.

Table 1. Variability of the parameter jump height in different types of jumps measured with inertial system (G-Walk) and infrared platform (Optojump Next).

\begin{tabular}{ccccccc}
\hline \multirow{2}{*}{$\begin{array}{c}\text { Methods of study and values for in- } \\
\text { dividual modes of implementation }\end{array}$} & \multicolumn{3}{c}{$\begin{array}{c}\text { Inertial sensor } \\
\text { (G-Walk) }\end{array}$} & \multicolumn{3}{c}{$\begin{array}{c}\text { Optical platform } \\
\text { (OptojumpNext) }\end{array}$} \\
\cline { 2 - 8 } Jump height (cm) \\
\hline Statistical parameter & SJ & CMJ & CMJA & SJ & CMJ & CMJA \\
\hline Mean & 44.66 & 45.22 & 56.30 & 29.01 & 30.04 & 36.84 \\
Std. Error of Mean & 1.03 & 0.96 & 1.28 & 0.70 & 0.75 & 1.07 \\
Median & 44.60 & 46.05 & 57.10 & 29.15 & 29.80 & 36.90 \\
Mode & 43.80 & 41.80 & 56.60 & 28.60 & 27.00 & 29.70 \\
Std. Deviation & 5.84 & 5.44 & 7.15 & 3.99 & 4.24 & 5.97 \\
Skewness & 0.123 & -0.653 & -0.040 & -0.329 & -0.766 & 0.014 \\
Kurtosis & 0.318 & 0.595 & 1.060 & -0.552 & 0.861 & 0.321 \\
Range & 27.20 & 23.00 & 36.30 & 14.80 & 18.60 & 26.70 \\
Minimum & 31.40 & 31.70 & 38.90 & 21.20 & 17.90 & 24.30 \\
Maximum & 58.60 & 54.70 & 75.20 & 36.00 & 36.50 & 51.00 \\
CV\% & 13.1 & 12.0 & 12.7 & 13.7 & 14.1 & 16.2 \\
\hline & \multicolumn{7}{c}{} & & & & & \\
\hline
\end{tabular}


Skewness [As] and Kurtosis [Ex] are respectively in range between 0.014 to -0.766 and -0.321 to 1.060 (with critical values for all tested subjects $(\mathrm{n}=32) \mathrm{As}=0.854$ and $\mathrm{Ex}$ $=1.665)$, which defines the tested parameter as normally distributed. The normality of the results was reconfirmed from Shapiro-Wilk test of normality $(\mathrm{p}>.05)$.

The results in table 1 received from the accelerometer were higher than the results of the IR with systematic bias of: SJ $=15.6$ $\mathrm{cm} ; \mathrm{CMJ}=15.2 \mathrm{~cm} ; \mathrm{CMJA}=19.5$. The effect size $\left(\eta^{2}\right)$ was large for the three tests and equals to: $\mathrm{SJ}=.65 ; \mathrm{CMJ}=.69 ; \mathrm{CMJA}=.65$.

The normality of the distribution of the jump height for both measuring devices from Shapiro-Wilk test of normality and coefficients of As and Ex allowed us to use the, ICC, ANOVA and Bland - Altman plot.

We made ICC of all of the results and we achieved strong consistency of the results between the two measurement devices. The relationship between $\mathrm{SJ}_{(\mathrm{G}-w a l k)}$ and $\mathrm{SJ}_{(\mathrm{IR})}$ was $\mathrm{R}=.91(\mathrm{p}<.05)$ with limit of agreements [LA] in range of 0.81-0.96. The correlation between $\mathrm{CMJ}_{(\mathrm{G}-\text {-walk) }}$ and $\mathrm{CMJ}_{(\mathrm{IR})}$ was $\mathrm{R}=.92(\mathrm{p}<.05)$ with LA in range of 0.84-0.96. The lowest level of correlation was between $\mathrm{CMJA}_{(\mathrm{G}-w a l k)}$ and $\mathrm{CMJA}_{(\mathrm{IR})}$ that was $\mathrm{R}=.87(\mathrm{p}<.05)$ with LA in range of 0.68-0.93.

We could observe important differences between the results of the two measuring devices when we performed ANOVA for SJ $\left(\mathrm{F}_{0,05}<\mathrm{F}_{\text {emp. }}=156.7\right), \mathrm{CMJ}\left(\mathrm{F}_{0,05}<\mathrm{F}_{\text {emp. }}=154.9\right)$ and CMJA $\left(\mathrm{F}_{0,05}<\mathrm{F}_{\text {emp }}=135.2\right)$. These differences were graphically presented through the Bland-Altman plot (Figure 2, Figure 3 and Figure 4) on the reliability of the measured parameters with the two devices. The upper and lower lines represent 95\% confidential interval with means $\pm 1.96 \mathrm{SD}$ of the differences $\left(\mathrm{SJ}_{\mathrm{LA}}: 9.92-21.37 \mathrm{~cm}\right.$; $\mathrm{CMJ}_{\mathrm{LA}}: 10-20.25$ $\mathrm{cm} ;$ CMJA $\left._{\mathrm{LA}}: 10.56-28.35 \mathrm{~cm}\right)$.

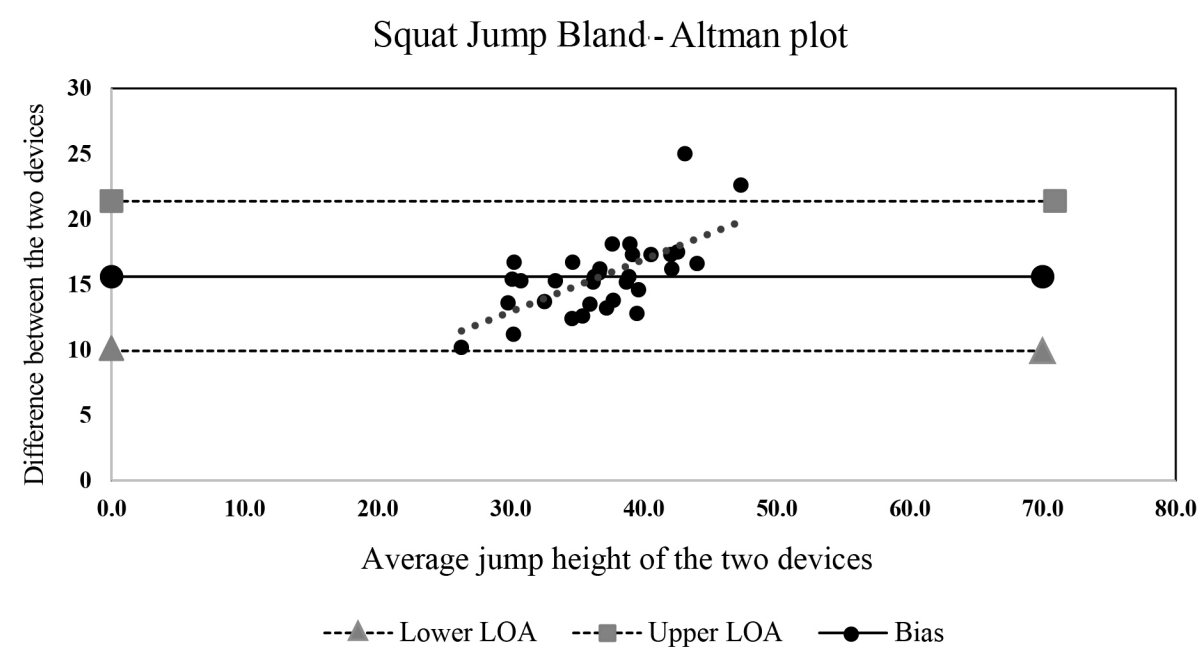

Figure 2. Bland-Altman plot between the OptojumpNext IR platform and G-walk accelerometer in the Squat Jump test 
CMJ Bland - Altman plot

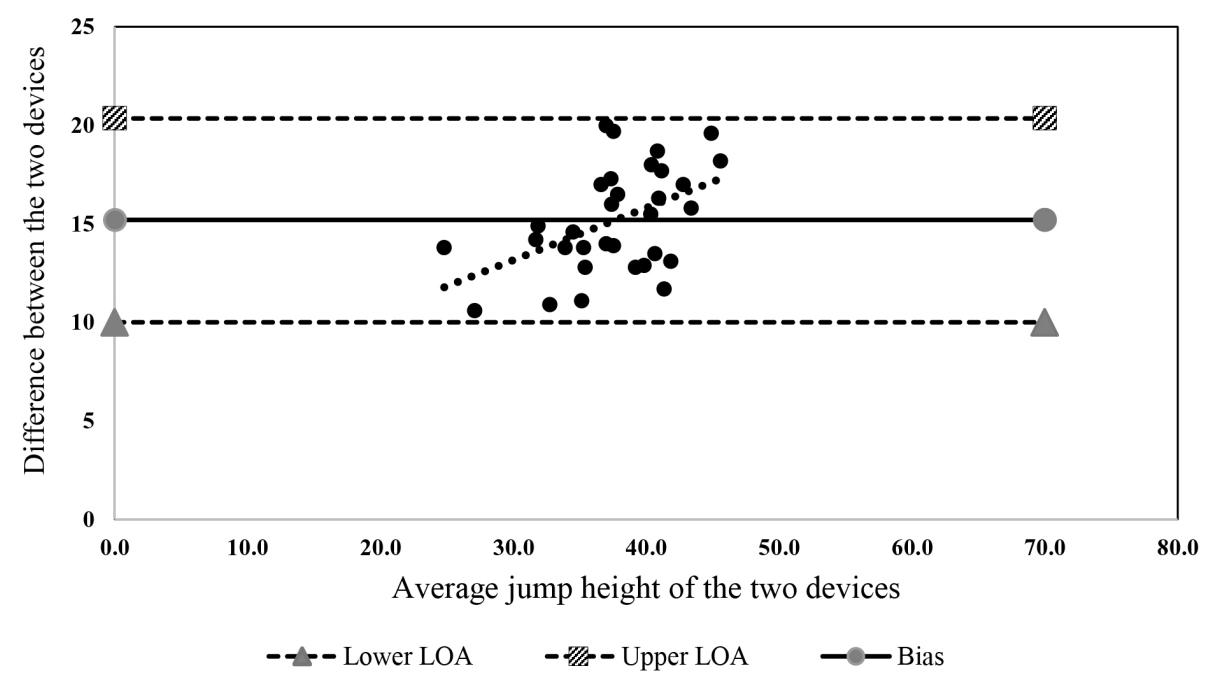

Figure 3. Bland-Altman plot between the OptojumpNext IR platform and G-walk accelerometer in the Counter Movement Jump test

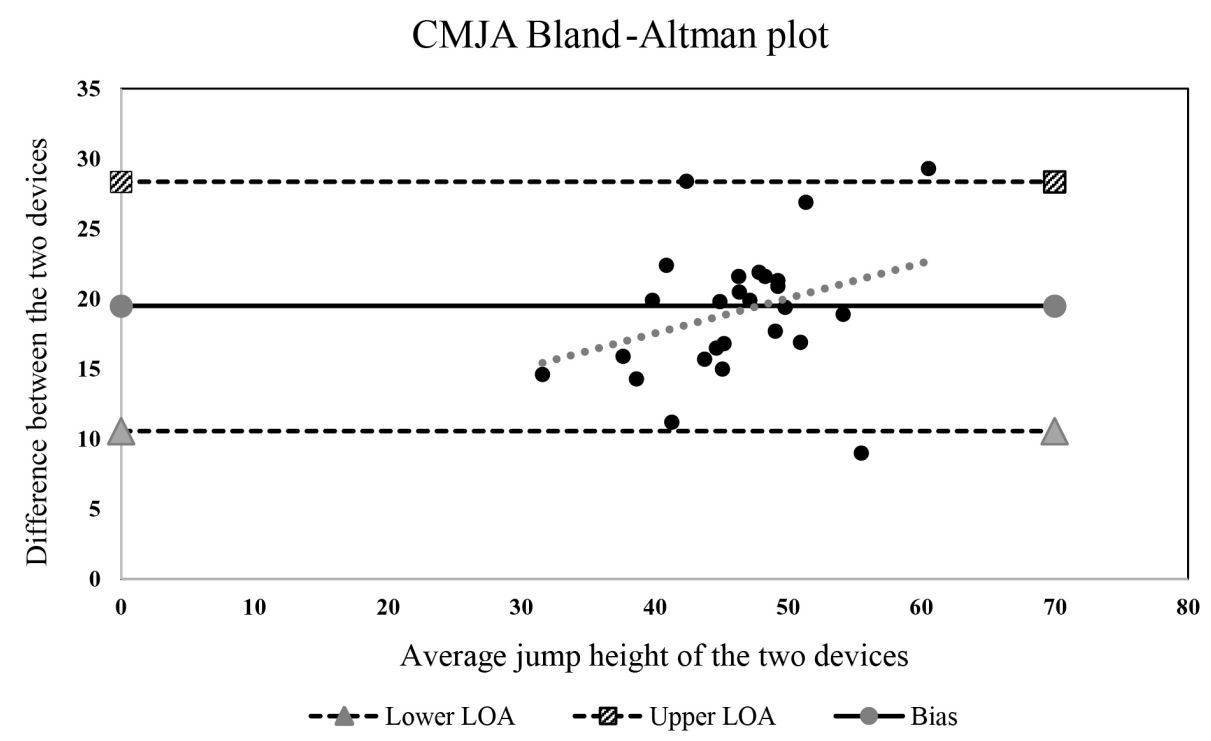

Figure 4. Bland-Altman plot between the OptojumpNext IR platform and G-walk accelerometer in the Counter Movement Jump with Arm Swing test

In order to apply our theoretical knowledge This way we can transform the result from the into practice we made a linear regression mod- IR device and predict the values of the G-walk el of the results of the three tests (Table 2). accelerometer.

Table 2. Linear regression equations for calibration of the results of the IR to $G$-walk

\begin{tabular}{ccccc}
\hline Independent variable & $\begin{array}{c}\text { Dependent } \\
\text { variable }\end{array}$ & Regression equation & $\begin{array}{c}\text { Fisher } \\
\text { criterion }\end{array}$ & $\begin{array}{c}\text { Level of signifi- } \\
\text { cance }\end{array}$ \\
\hline $\mathbf{S J}_{(\mathrm{IR})}$ & $\mathrm{SJ}_{(\mathrm{G}-\text { walk) }}$ & $\mathrm{y}=1.3052 \mathrm{x}+6.7926$ & 115.3 & .001 \\
$\mathbf{C M J}_{(\mathrm{IR})}$ & $\mathrm{CMJ}_{(\mathrm{G}-\text { walk) }}$ & $\mathrm{y}=1.1313 \mathrm{x}+11.234$ & 103.5 & .001 \\
$\mathbf{C M J A}_{(\mathrm{IR})}$ & $\mathrm{CMJA}_{(\text {G-walk) }}$ & $\mathrm{y}=0.9289 \mathrm{x}+22.078$ & 43.7 & .001 \\
\hline
\end{tabular}




\section{DISCUSSION}

Our research had similar results and, as we hypothesized, there were differences in the jump height of devices that used different methods for its calculation. Every manufacturer assured the reliability and validity of their system with force plate measures - the golden standard in this type of measurements (Hatze, 1998). This method used the ground reaction forces of the contact time of the take-off to calculate the height of the jump. Other authors, such as Aragón-Vargas (2000), stated that the golden standard should be video analysis. Different systems use various methods such as flight time, length of a pulled cord or rope, video analysis, vertical displacement of CM or the velocity of taking-off of CM. A great number of surveys were made in this manner using various measuring devices, which caused greater variation of the results. The most frequently used method for measuring jump height is based on the flight time mainly because it is easily accessible, even though many authors find some limitations of this method (Markovic et al., 2004; Enoksen et al., 2009; Requena et al., 2012; Nordin et al., 2014).

According to Bosco et al., (1983), Hatze (1998), Kibele (1998), Aragon-Vargas (2000), Moir (2008), Enoksen et al. (2009) these differences and limitations are expressed as follows:

It is presumed that the upward and downward part of the flight time are of equal length, which is not correct;

Landing in a different place from the takeoff place means greater flight time, therefore higher result;

From biomechanical point of view, the lower limbs are more flexed during the landing rather than the take-off.

The other method that we used in this research is based on the accelerometer data. The main disadvantage of measuring jump height by the velocity of the take-off of CM was that the highest velocity was reached prior to the jump itself (Hatze, 1998; Enoksen et al., 2009). Another main difference which we could observe and was also in agreement with other research was the statistically valid difference between the results of all the tests for both measuring devices. The results acquired in our research were similar to those stated in other research papers. The main argument we could give was that the accelerometer overestimates the received result, while the infrared platform underestimates it (Bosco et al. 1983; Aragon-Vargas, 2000). The results by Moir (2008) were not in agreement with the previous findings. However, most authors reported lower values for the results when the flight time method was used as a measuring technique (Markovic et al., 2004; Slinde et al., 2008).

The method of measuring the vertical displacement of CM was also verified and thought to be appropriate according to the data collected by various authors (Nuzzo et al., 2004; Cronin et al., 2011; Buckthorpe et al., 2012; Choukou et al., 2014). However, some authors thought that its accuracy was questionable (Aragon-Vargas, 2000; Moir, 2008; Enoksen et al., 2009).

All of these devices and methods had one main goal - increasing the measuring accuracy of the parameters which determine explosive power. The most accurate measuring device was still not specified, however there were two of them widely accepted with time and practice: video analysis and force plate. Unfortunately, the majority of the measuring in the field was done with other, less expensive and more user-friendly measuring devices. The reasons for that were as follows: firstly, these platforms were expensive and could mostly be found in laboratories and secondly - there was the need for quick and easy data collecting during field work.

From our findings we could conclude that the measuring devices register concurrent validity on the three of the tests. The strong cor- 
relational coefficients between two the measurements $(\mathrm{R}=0,87-0,92)$ on the same tests proved it. Despite a significant difference in measuring the parameter both systems could identify better and worse results. ICC varied across different authors which we related to the different measuring devices and their accuracy.

In sports theory we could find different tests that were used for measuring jump height (or in other words vertical displacement of CM) (Aragon-Vargas, 2000; Markovic et al., 2004; Enoksen et. al., 2009; Nordin et al., 2014). However, SJ, CMJ and CMJA were the most frequently used ones (Requena et al., 2012; Attia et al., 2017). The results from these tests are influenced by four main parameters of execution (Cheng et al., 2008). The first one is linked to the usage of arms and their movement (Cheng et al., 2008). The second one is about the depth of the squat. The deeper the squat the higher the result, because of the preliminary stretching of the muscles (Gheller et al., 2014; Laffaye et al., 2014). The third one is the position of the lower limbs while in the air, because if we lift them, we could achieve a greater result. The fourth one is about the same position of take-off and landing, because if you landed at a different place this would mean that you did not jump only in the vertical plane (Markovic et al., 2004; Glatthorn et al., 2011).

The method integrated in OptojumpNext (flight time method) was validated by Garcia-Lopez et al., (2005), Glatthorn et al., (2011), and Attia et al., (2017). The researchers must have in mind that the actual jump height is by $0,3 \mathrm{~cm}$ greater than the received one because the sensor is $0.3 \mathrm{~cm}$ above the surface on which the bars are situated. Other research by Balsalobre-Fernandez et al., (2014) and Magrum et al., (2018) showed that the infrared platforms are a reliable source of information for the sports scholars.
Our results were similar to Balsalobre-Fernandez et al., (2014). These authors found that OptojumpNext has theoretical precision usually $\pm 1.8 \mathrm{~mm}$, but it should be decreased in proportion with the increase of the jump height. However, the current Bland-Altman plots with the regression lines show that higher jumps correspond to larger differences between devices.

Similar surveys about the validity and reliability of tests have been done by numerous authors with different systems and devices as well as different methods of determining the jump height (Bosco et al., (1983); Aragon-Vargas, (2000); Hoffman and Kang, (2002); Leard et al., (2007); Szmuchrowski et al., (2007); Borges Junior et al, (2011); Buckthorpe et al., (2012); Balsalobre-Fernandez et al., 2014; Monnet et al., (2014); Słomka, (2017)). The result of SJ and CMJ presented in Table 1 allowed us to conclude, that despite being the same age young football players exhibit different skills when it comes to using the elastic forces of the extending muscles of the lower limbs. Our results are a proof to this statement because the difference between these jump heights must be greater for CMJ compared to SJ (Bobbert et al., 1996) In our case it was just around $1 \mathrm{~cm}$. Other scientists had come to similar conclusions (Brown et al., 2001; Peev et al., 2017). Also, some authors took into account the more accurate measuring of SJ rather than CMJ (Enoksen et al., 2009).

The difference between CMJ and CMJA is the same as reported in the literature, between $20-21 \%$ for different measuring devices (Slinde et al., 2008). We must consider the fact that most of the football players cannot efficiently use the arm swings (Miladinov, 1998). Evidence for these conclusions is the greatest range of the presented jump height in Table 1 of this test for both devices. 
It also has to be taken into consideration that during the tests the $\mathrm{CM}$ increases by up to $4 \mathrm{~cm}$ with the lifting of the arms, while the belt with the accelerometer is fixed on the waist and this type of increase is impossible (Monnet et al., 2014).

\section{STRENGTHS AND LIMITATIONS}

The main contribution of the research is the regression models for comparing the results of the IR and G-walk devices. In general, this research confirms the results of other similar reports that the accelerometer method shows greater value of the jump height. As a limitation of the research we can point the lack of a test-retest method for validity of the measured results which can be a direction for future research.

\section{CONCLUSIONS}

Based on the results of this study, the following conclusions were drawn as recommendations for the sport practice:

The two devices have good consistency of the collected results;

The data collected via two devices showed significant difference of the jump heights.

\section{RECOMMENDATIONS}

Scientific research or monitoring the trends of development of explosive power in sport should be done by using a single method. Comparison of values and data in the scientific literature derived by using different methods and devices must be used with caution.

\section{ACKNOWLEDGEMENTS}

Our thanks to National Sports Academy "Vassil Levski" and Youth academy of PFC "Levski"- Sofia for their help in conducting the research. Special thanks to Engineer Silvena Todorova for the graphical design of the pictures.

\section{REFERENCES}

Aragón-Vargas, L. F. (2000). Evaluation of four vertical jump tests: Methodology, reliability, validity, and accuracy, Measurement in physical education and exercise science, Vol.4, No. 4, pp. 215-228.

Attia, A., Dhahbi, W., Chaouachi, A., Padulo, J., Wong, D. P., and Chamari, K. (2017). Measurement errors when estimating the vertical jump height with flight time using photocell devices: the example of Optojump, Biology of sport, Vol.34, No. 1, pp. 63-70.

Balsalobre-Fernández, C., Tejero-González, C. M., del Campo-Vecino, J., and Bavaresco, N. (2014). The concurrent validity and reliability of a low-cost, high-speed camera-based method for measuring the flight time of vertical jumps, The Journal of Strength \& Conditioning Research, Vol.28, No. 2, pp. 528-533.

Bobbert, M.F., Gerritsen, K.G., Litjens, M.C. and Van Soest, A.J. (1996). Why is countermovement jump height greater than squat jump height? Medicine and science in sports exercise, Vol. 28 No.11, pp. 1402-12.

Borges Júnior, N. G., Borges, L., Dias, J. A., Wentz, M. D., Mattos, D. J. D. S., Petry, R., and Domenech, S. C. (2011). Validity of a new contact mat system for evaluating vertical jump, Motriz: Revista de Educação Física, Vol.17, No. 1, pp. 26-32.

Bosco, C., Luhtanen, P. and Komi, P.V. (1983). A simple method for measurement of mechanical power in jumping, European journal of applied physiology and occupational physiology, Vol.50, No. 2, pp. 273-282.

Brown, L.E. and Weir, J.P. (2001). Accurate assessment of muscular strength and power, Journal of Exercise Physiology Online, August; Vol.4, No. 3, pp. 1-21.

Buckthorpe, M., Morris, J. and Folland, J. P. (2012). Validity of vertical jump measurement devices. Journal of sports sciences, Vol.30, 
No. 1, pp., 63-69.

Cheng, K.B., Wang, C.H., Chen, H.C., Wu, C.D., and Chiu, H.T. (2008). The mechanisms that enable arm motion to enhance vertical jump performance - A simulation study, Journal of Biomechanics, Vol. 41, pp. 1847-1854.

Choukou, M-A., Laffaye, G. and Taiar, R. (2014). Reliability and validity of an accelerometric system for assessing vertical jumping performance, Biology of Sport Vol.31, No. 1, pp. 55-62.

Cronin, J. B., Hing, R. D., and McNair, P. J. (2004). Reliability and validity of a linear position transducer for measuring jump performance, Journal of Strength \& Conditioning Research, Vol.18, No. 3, pp. 590-593.

Cunha, G.S., Cumming, S. P., Valente-dosSantos, J., Duarte, J. P., Silva, G., Dourado, A. C., and Coelho-e-Silva, M. (2017). Interrelationships among Jumping Power, Sprinting Power and Pubertal Status after Controlling for Size in Young Male Soccer Players, Perceptual and motor skills, Vol.124, No. 2, pp. 329-350.

Damyanova, R. (2012). Teoretichni osnovi na testovoto izmervane $\mathrm{i}$ otsenyavane vav fizicheskoto vazpitanie i sporta, NSA PRES, Sofia, pp. 264 // Дамянова, P. (2012). Теоретични основи на тестовото измерване и оценяване във физическото възпитание и спорта, НСА ПРЕС, София , стр. 264.

Di Salvo, V., Pigozzi, F., González-Haro, C, Laughlin, M.S., and De Witt, J.K. (2013). Sprinting analysis of elite soccer players during European Champions League and UEFA Cup matches, International Journal of Sports Medicine, Vol.34, pp. 526-532.

Enoksen, E., Tønnessen, E. and Shalfawi, S. (2009). Validity and reliability of the Newtest Powertimer 300-series ${ }^{\circledR}$ testing system, Journal of sports sciences, Vol.27, No. 1, pp. 77-84.
Garcia-Lopez, J., Peleteiro, J., Rodgriguez-Marroyo, J. A., Morante, J. C., Herrero, J. A., and Villa, J. G. (2005). Validation of a new method that measures contact and flight times during vertical jump, International Journal of Sports Medicine, Stuttgart, Vol.26, No. 4, pp. 294-302.

Gheller R.G., Pupo J.D., de Lima L.A.P., de Moura B.M. and dos Santos S.G. (2014). Effect of squat depth on performance and biomechanical parameters of countermovement vertical jump, Revista Brasileira de Cineantropometria \& Desempenho Humano, Vol.16, No. 6, pp. 658-668.

Glatthorn, J. F., Gouge, S., Nussbaumer, S., Stauffacher, S., Impellizzeri, F. M., and Maffiuletti, N. A. (2011). Validity and reliability of Optojump photoelectric cells for estimating vertical jump height, Journal of Strength \& Conditioning Research, Vol.25, No. 2, pp. 556-560.

Hatze, H. (1998). Validity and reliability of methods for testing vertical jumping performance, Journal of applied biomechanics, Vol.14, No. 2, pp. 127-140.

Haugen, T. and Seiler, S. (2015). Physical and physiological testing of soccer players: why, what and how should we measure? Sport science, Vol 19, pp.10-27.

Haugen, T.A., Tønnessen, E. and Seiler, S. (2013). Anaerobic performance testing of professional soccer players 1995-2010, International Journal of Sports Physiology and Performance, Vol.8, No. 2, pp.148-156.

Hoffman, J. R., and Kang, J. (2002). Evaluation of a new anaerobic power testing system, Journal of Strength \& Conditioning Research, Vol.16, No. 1, pp. 142-148.

Kibele, A. (1998). Possibilities and limitations in the biomechanical analysis of countermovement jumps: A methodological study, Journal of Applied Biomechanics, Vol.14, No. 1, pp. 105-117. 
Klavora, P. (2000). Vertical-jump tests: A critical review, Strength and Conditioning Journal, Vol.22, No. 5, pp. 70-75.

Laffaye, G., Wagner, P.P. and Tombleson, T.I.L. (2014). Countermovement jump height: Gender and sport-specific differences in the force-time variables, Journal of Strength $\&$ Conditioning Research, Vol.28, No. 4, pp. 1096-1105.

Leard, J.S., Cirillo, M. A., Katsnelson, E., Kimiatek, D. A., Miller, T. W., Trebincevic, K., and Garbalosa, J. C. (2007). Validity of two alternative systems for measuring vertical jump height, Journal of Strength \& Conditioning Research, Vol.21, No. 4, pp. 1296-1299.

Magrum, E. D., Wagle, J. P., DeWeese, B. H., Sato, K., and Stone, M. H. (2018). The Use of an Optical Measurement System to Monitor Sports Performance, Sports, Vol.6, No. 1, pp. 15.

Markovic, G., Dizdar, D., Jukic, I., and Cardinale, M. (2004). Reliability and factorial validity of squat and countermovement jump tests, Journal of Strength \& Conditioning Research, Vol.18, No. 3, pp. 551-555.

McFarland, I. T., Dawes, J. J., Elder, C. L. and Lockie, R. G. (2016). Relationship of two vertical jumping tests to sprint and change of direction speed among male and female collegiate soccer players, Sports, Vol.4, No. 1, pp. 11.

Miladinov, O. (1998). Izsledvane na vzrivnata sila pri 18-godishni futbolisti, Sport i nauka, Vol. 1, pp. 17-21// Миладинов, О. (1998). Изследване на взривната сила при 18-годишни футболисти, Спорт и наука, Vol. 1, pp. 17-21.

Moir, G. L. (2008). Three different methods of calculating vertical jump height from force platform data in men and women, $\mathrm{Mea}$ surement in Physical Education and Exercise Science, Vol.12, No. 4, pp., 207-218.

Monnet, T., Decatoire, A. and Lacouture.
P. (2014). Comparison of algorithms to determine jump height and flight time from body mounted accelerometers, Sports Engineering, Vol.17, No. 4, pp., 249-259.

Nordin, A., Kivi, D., Zerpa, C. and Newhouse, I. (2014). Comparison of methods for assessing vertical jump height performance, International Society of Biomechanics in Sports, 681-684.

Nuzzo, J. L., Anning, J. H. and Scharfenberg, J.M. (2011). The reliability of three devices used for measuring vertical jump height, Journal of Strength and Conditioning Research, Vol.25, No. 9, pp. 2580-90.

Peev, P. (2014). Interrelation between speed abilities and speed strength abilities and speed endurance of 13-14 years football players, Proceeding book, 9th FIEP European Congress and 7th International Scientific Congress ,Sport, Stress, Adaptation”, Sofia 9-12 October, pp. 1007.

Peev, P., Gadev, M., Hristov, O., Petrova, B. and Mihaylov, I. (2017). Vzaimovrazka mezhdu priznatsite harakterizirashti anaerobnata mosht i raznovidnosti na otskotsi vav vertikalnata ravnina pri 14-godishni futbolisti Leka atletika i nauka, Vol. 1, №17, pp. 25-32 // Пеев, П., Гъдев, М., Христов, О., Петрова, Б., и Михайлов, И. (2017). Взаимовръзка между признаците характеризиращи анаеробната мощ и разновидности на отскоци във вертикалната равнина при 14-годишни футболисти, Лека атлетика и наука Брой 1, № 17, стр. 25-32.

Rampinini, E., Bishop, D., Marcora, S. M., Bravo, D. F., Sassi, R., and Impellizzeri, F. M. (2007). Validity of simple field tests as indicators of match-related physical performance in top-level professional soccer players, International journal of sports medicine, Vol. 28, No. 03, pp. 228-235.

Requena, B., García, I., Requena, F., de Villarreal, E. S. S., and Pääsuke, M. (2012). 
Reliability and validity of a wireless microelectromechanicals based system (Keimove $^{\mathrm{TM}}$ ) for measuring vertical jumping performance, Journal of sports science \& medicine, Vol.11, No. 1, pp. 115-122.

Rouis, M., Coudrat, L., Jaafar, H., Attiogbé, E., Vandewalle, H., and Driss, T. (2016). Effects of ethnicity on the relationship between vertical jump and maximal power on a cycle ergometer, Journal of human kinetics Vol.51, No. 1, pp. 209-216.

Slinde, F., Suber, C., Suber, L., Edwén, C. E., and Svantesson, U. (2008). Test-retest reliability of three different countermovement jumping tests, Journal of Strength and Condi- tioning Research, Vol.22, No. 2, pp. 640-644.

Słomka, K. J., Sobota, G., Skowronek, T., Rzepko, M., Czarny, W., and Juras, G. (2017). Evaluation of reliability and concurrent validity of of two optoelectric systems used for recording maximum vertical jumping performance versus the gold standard, Acta of bioengineering and biomechanics, Vol.19, No. 2, pp. 141-147.

Szmuchrowski, L. A., Ferreira, J. C., da Silva Carvalho, R. G., Barroso, T. M., and Ferreira, R. M. (2007). Reliability of a flight time measurement instrument during vertical jump, In ISBS-Conference Proceedings Archive, December, Vol.1, No. 1, pp.

\section{Corresponding author:}

Petar Peev

Track and Field Athletics Department National Sports Academy "Vassil Levski"

21, Acad. Stefan Mladenov. Str. Studentski grad, 1700

Sofia, Bulgaria

E-mail: petar.r.peev@gmail.com 